\title{
Rézlemezek ultrahangos hegesztésénél előforduló hibák elemzése
}

\section{Investigation of Imperfections Formed in the Ultrasonic Welding of Copper Sheets}

\author{
Kovács Tünde Anna \\ Óbudai Egyetem, Bánki Donát Gépész és Biztonságtechnikai Mérnöki Kar, Anyag és Alakítástechnológiai \\ Intézeti Tanszék, Budapest, Magyarország, kovacs.tunde@bgk.uni-obuda.hu
}

\begin{abstract}
Ultrasonic welding is a very useful and simple welding process. It is suitable for establishing a joint between thin sheets and dissimilar metals with short preparation and finish work time [1]. Some welding defects were detected due to less than optimal ultrasonic welding parameters. These defects were ruptures, surface colour change and unacceptable deformations. This article aims to identify these failures and their causes.
\end{abstract}

Keywords: copper, ultrasonic welding, weld imperfections, heat affected zone.

\section{Összefoglalás}

Az ultrahangos hegesztés nagyon hasznos és egyszerű kezelést kívánó hegesztési eljárás. Vékony lemezek hegesztésére, valamint ezek vegyes kötéseinek létrehozására alkalmas rövid előkészítési idő, illetve utómunka mellett [1]. Az ultrahangos hegesztés során azonban károsodás is bekövetkezhet a nem megfelelő hegesztési változók alkalmazása következtében. Ezek a hegesztési eltérések a repedésképződés, a felület elszíneződése, valamint a túlzott deformáció. Jelen tanulmány az eltéréseket rendszerezi és megkísérli a kialakulásuk okainak feltárását.

Kulcsszavak: réz, ultrahangos hegesztés, hegesztési eltérés, hőhatásövezet.

\section{Bevezetés}

A vékony lemezek hegesztése fontos ipari feladat. Alkalmazható vékony lemezek esetében forrasztás, ragasztás és hegesztés is. A jó vezetőképesség megtartása miatt fémes kapcsolatot javasolt hegesztéssel létrehozni. Hegesztés során mindig törekedni kell arra, hogy a hegesztés következtében kialakuló kötés, a hőhatásövezet és az alapanyag azonos kémiai összetételü, szerkezetű s ezáltal azonos mechanikai tulajdonságú legyen. Amennyiben azonban a hegesztés során eltérések keletkeznek, akkor a technológia felülvizsgálatára vagy más eljárás alkalmazására van szükség.

Az ultrahangos hegesztés igen előnyös az elektronikai iparban, mivel a fémes kapcsolat kialakítása során nem keletkezik nagy hőhatás, nem szükséges hegesztő- vagy forrasztóanyag, fémes kapcsolat jön létre a darabok között, elérhető a megfelelő kötésszilárdság, nincs jelentős deformáció.

\section{Elméleti háttér}

\subsection{Kifáradás, fáradási szilárdság}

A repedésképződés és a törés fémek esetében gyakran a kifáradási jelenséggel magyarázható. A nemvas- vagy titánalapú övözetek esetén (Al, $\mathrm{Mg}, \mathrm{Cu})$ nem kifáradási határt, hanem fáradási szilárdságot határoznak meg. A fáradási szilárdság az a feszültségszint, melyet még adott ismétlés (pl. 107) esetén elvisel, ui. a diagramon látszik, hogy a görbének nincs vízszintes aszimptotája (1. ábra). 


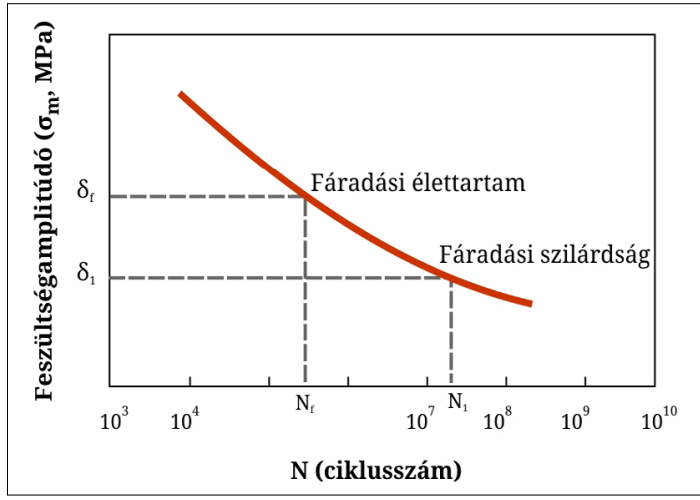

1. ábra. A fáradási szilárdság ábrázolása a ciklusszám-feszültségamplitúdó diagramon [2]

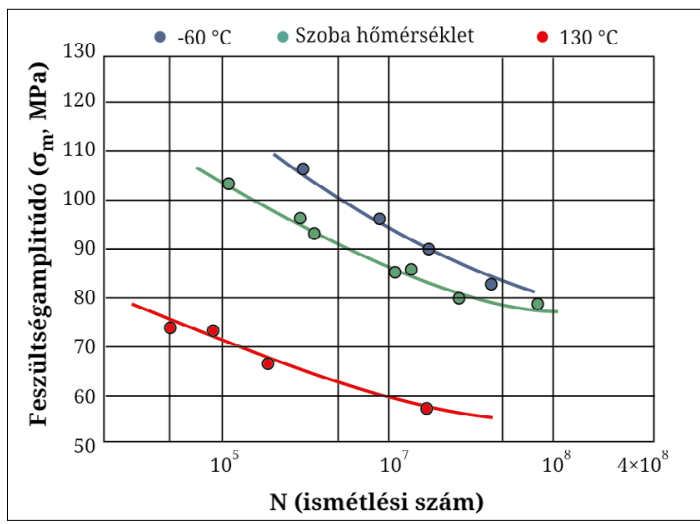

2. ábra. Fáradási szilárdság a hőmérséklet függvényében, lágyított színrézre [2]

A fáradási szilárdság nem anyagjellemző, értékét befolyásolja a szemcseméret, korrózió, frekvencia és a vákuum jelenléte, a középfeszültség, képlékenység, felületi érdesség, mikroszerkezet (bemetszésérzékenység), hőmérséklet [3]. A hőmérséklet növekedésével a fáradási szilárdság csökken (2. ábra).

\subsection{Az ultrahangos hegesztés elméleti hát- tere}

Az ultrahangos hegesztés nem új eljárás, több évtizede alkalmazzák az iparban, ennek ellenére fémtani háttere még nem teljesen ismert. Ez a hegesztési eljárás vékony lemezek összekapcsolására alkalmas, a sajtolóhegesztési eljárások közé tartozik. A kötés kialakításához nagyfrekvenciás ultrahangot és sajtolóerőt alkalmaznak.

Az ultrahang hatása a diszlokációk mozgására a fémmegmunkálás területén ismert elmélet. Az ultrahangos hegesztés alapja az ultrahang keltette rezgésnek a fémes anyag képlékenységét elősegítő hatása, mivel a kö-

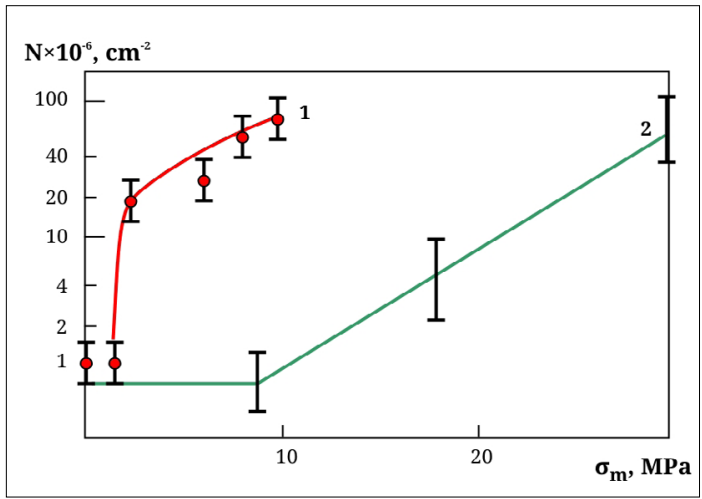

3. ábra. Diszlokációsürüség a feszültségamplitúdó függvényében (1) $\mathrm{Al} 20^{\circ} \mathrm{C}$ és (2) $\mathrm{Cu} 450^{\circ} \mathrm{C}$ [7]

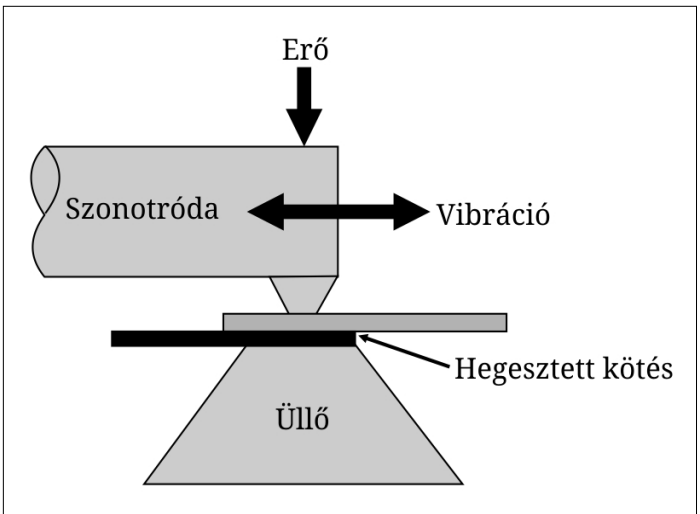

4. ábra. Az ultrahangos hegesztés vázlata [1]

tés képlékeny alakváltozással jön létre [4-6]. A 3. ábra mutatja, hogy a diszlokációsűrüség az ultrahang hatás-idő függvényében változik. Ez az egyik magyarázata annak, hogy a mechanikai tulajdonságok is változnak.

Az ultrahangos hegesztés a hidegsajtoló hegesztések csoportjába tartozik. Az ultrahangos vibráció, a szorítónyomás és a vibrációból adódó súrlódás közrejátszik a kötés létrejöttében.

A hegesztés során a felületek között súrlódás lép fel, melynek következtében a darabok a kötési zónában felhevülnek (4. ábra).

A keletkező hőmérséklet függ egyrészt az anyag fizikai tulajdonságaitól, másrészt a hegesztési változóktól. Alumínium- és rézlemezek esetében jelentős hőmérséklet-növekedés tapasztalható. Hegesztési gyakorlatban hőmérséklet ellenőrzésére alkalmazott hőkrétával elvégzett mérésekkel igazolt, hogy réz esetében $500{ }^{\circ} \mathrm{C}$-ot biztonsággal elérhet a hegesztett kötés. Ez a hőmérséklet azonban már meghaladja az újrakristályosodás hőmérsékletét. 
A hegesztett kötés kialakulását képlékeny deformáció segíti. Az 5. ábrán a kalapács (vagy szonotródacsúcs) lenyomata látszik, a 6 . ábrán pedig a varrat metszeti képe. A szemcsék alakja deformált, mérete eltérő.

A kötés kialakításában nagy szerepe van az ultrahang hatására létrejövő diszlokációmozgásoknak, melyek segítik a képlékeny alakváltozást, ami a sajtoló hegesztési eljárásoknál a kötés kialakulásához szükséges. Az ultrahangos hegesztés tehát egy komplex hatásmechanizmussal létrejövő kötés. Az ultrahang és a súrlódási hő hatására a kötésben létrejöhet újrakristályosodás. A szemcseméret ezáltal megváltozhat, ezzel együtt pedig a kötés szilárdsága is.

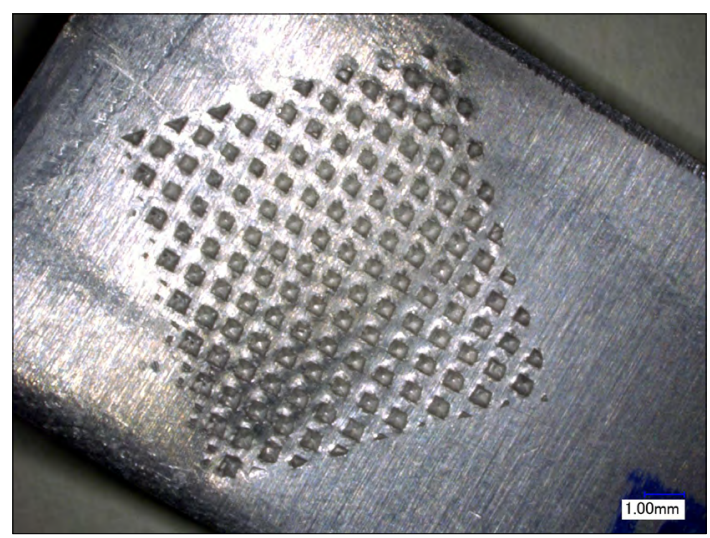

5. ábra. Ultrahangos hegesztéssel készített kötés felülete alumínium próbatesten

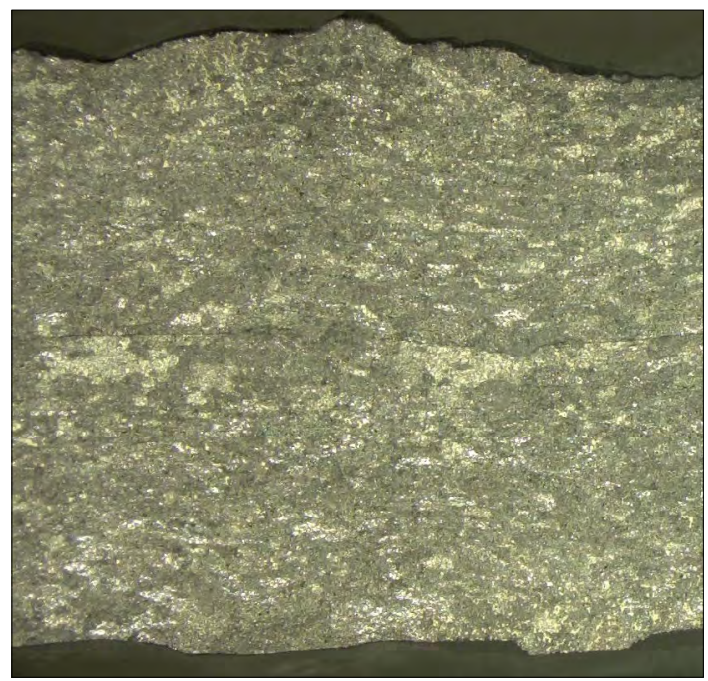

6. ábra. Ultrahangos kötés metszete (alumínium próbatest)

\section{Rézlemezek ultrahangos hegesztési kísérletei}

\subsection{Vizsgált anyag}

A réz igen kedvelt fém, már az ókorban is használták. Jól alakítható (szakadási nyúlása $\mathrm{A}=50 \%$ ), jó hő- és villamos vezető, korrózióval szemben kitűnő ellenállást mutat. Olvadási hőmérséklete $\left(1084^{\circ} \mathrm{C}\right)$ kisebb az acélokénál és nagyobb az alumíniuménál. Az ipari gyakorlatban jellemzően forrasztással kapcsolják össze a rézlemezeket, mivel a ponthegesztésük csak speciális elektródával és munkarenddel oldható meg, ömlesztőhegesztésük pedig nagy hőbevitellel jár. Kis hőbevitelü eljárások esetén, mint a lézersugaras hegesztés pedig a réz jó hővezetése és reflexiója okoz gondot [6-7].

Bár a réz széles körben alkalmazott fém az iparban, a szilárdsága nem jelentős (lágy állapotban: $\mathrm{R}_{\mathrm{m}}=240 \mathrm{MPa}, \mathrm{R}_{\mathrm{p} 0,2}=70 \mathrm{MPa}$, keménysége $30 \mathrm{HBS}$ ). Lágyított állapotban a fáradási szilárdság értéke 62-75 MPa [2]. Hidegalakítással (380-415 MPa), ötvözéssel és hőkezeléssel a szilárdság növelhető, de ezzel szemben más előnyös tulajdonságok, pl. a vezetőképesség, romlanak. Felhasználása a villamos iparban jellemző.

A hegesztési kísérletekhez tiszta réz (C1020) lemezeket alkalmaztunk, amely az elektronikai iparra jellemző alapanyag, mikroszerkezetét a 7. ábra mutatja. Lágy állapotú, $0,5 \mathrm{~mm}$ vastagságú, 99,90\% tisztaságú vörösréz (Szabványos jelölés: Cu-DHP, CW024A, EN 1172) lemez próbatesteket alakítottunk ki (15 mm széles, $60 \mathrm{~mm}$ hosszú).

\subsection{A hegesztőberendezés}

A hegesztés során alkalmazott frekvencia a berendezés által meghatározott $\mathrm{f}=20000 \mathrm{~Hz} \pm 50 \mathrm{~Hz}$. A kísérletekhez Branson Ultraweld L20 hegesztő

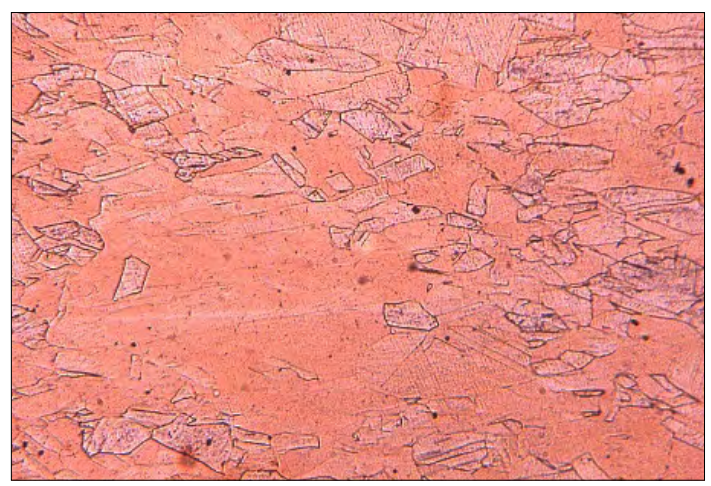

7. ábra. A réz mikroszerkezete 50 x nagyítás ammónium-hidroxid/ammónium-peroxid keverékkel maratva [7] 
berendezést alkalmaztam. A frekvencia mellett a további hegesztési változók a hegesztés időtartama t (s), rezgésamplitúdója A $(\mu \mathrm{m})$, az összeszorító erő $\mathrm{F}(\mathrm{N})$, a teljesítmény $\mathrm{P}(\mathrm{W})$, mely az (1) összefüggésből adódik, ahol $\mathrm{f}(\mathrm{Hz})$ a frekvencia:

$$
P=F \cdot A \cdot f
$$

Az üllő (12,5 × 12,5 mm méretű négyzet) és a szonotródacsúcs (14,5 × 12,5 mm-es téglalap) felülete eltérő. Lehetőség van hegesztés közben és után a varrat hűtésére levegőfúvatással.

A hegesztési változók menürendszerből választhatók. A „hegesztési energia” üzemmódot alkalmazva az ultrahang müködése a kívánt energia eléréséig tart. A „hegesztési idő” üzemmód esetén pedig meghatározott ideig tart az ultrahanghatás. A hegesztés munkarendjét a 8. ábra mutatja be.

A hegesztés során van egy előtartási idő adott tartónyomással, majd az ultrahangos rezgetés közben a szonotródafejre szerelt kalapács az üllőhöz a hegesztési nyomással szorítja össze a munkadarabokat (4. ábra). A szerszámacél üllő és kalapács felületei érdesítettek, hogy a munkadarabokkal ne hegedjenek össze [8-9].

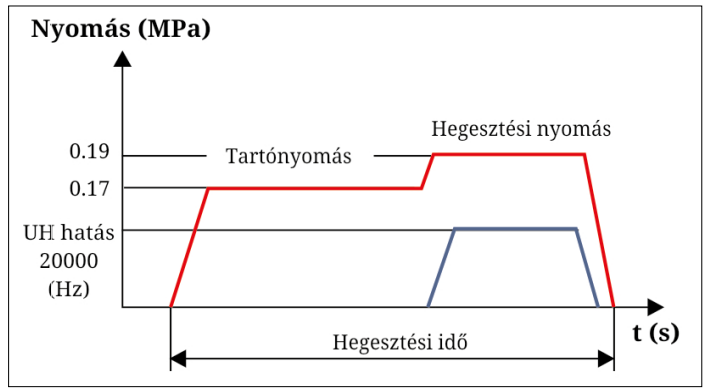

8. ábra. Az ultrahangos hegesztés munkarendje

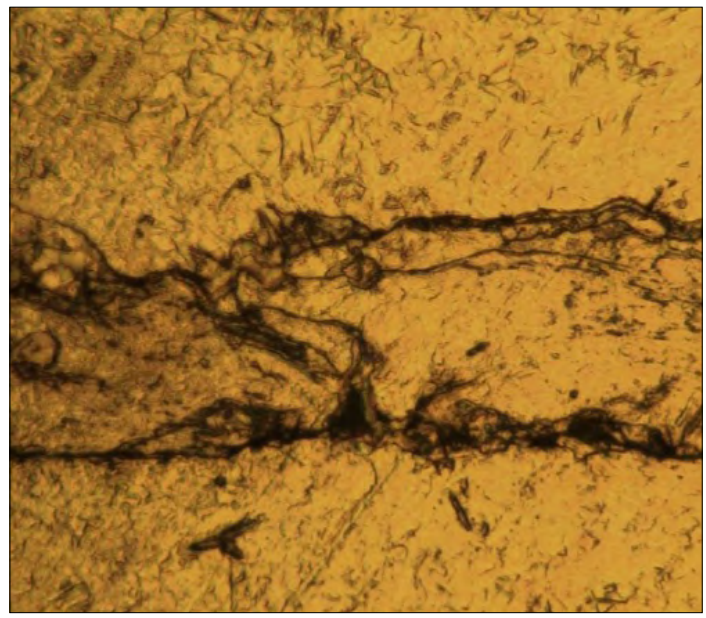

9. ábra. Repedés az ultrahangos hegesztett kötésben, réz próbatest

\subsection{A hegesztési varratok eltérései}

Különböző beállításokkal végeztünk hegesztési kísérleteket. Hegesztési idő üzemmód alkalmazása során az ultrahangos hegesztési idő pontosan beállítható. Előkísérleteket végeztünk annak meghatározására, hogy melyik hegesztési változó változtatása okoz jelentős különbséget a hegesztett varrat kialakítása során a deformáció és varrat szilárdsága szempontjából.

A kísérletek eredményei azt mutatták, hogy a rezgés amplitúdójának változtatása, valamint a hegesztési idő jelentős hatást gyakorol a hegesztett kötés tulajdonságaira [10]. A 9. ábra nem megfelelő kötést mutat a varrat keresztmetszeti képén. A kötés nem jött létre, a varrat metszetében repedések láthatóak.

A hegesztés során túlhevülés is létrejöhet, melynek hatására a munkadarabok megolvadhatnak. A 10. ábrán látható kötés metszetében látható olvadt részek is ezt mutatják. Ultrahangos hegesztés esetében ez nem megfelelő kötést hoz létre.

Egyes hatástényezők együttes hatására repedés, törés képződése is előfordulhat, ilyen esetet mutat a 11. ábra.

A hegesztési repedések jellemzően az összekapcsolt felület szélén indulnak el, és az esetek többségében a 11. ábrán látható módon töréssel végződnek.

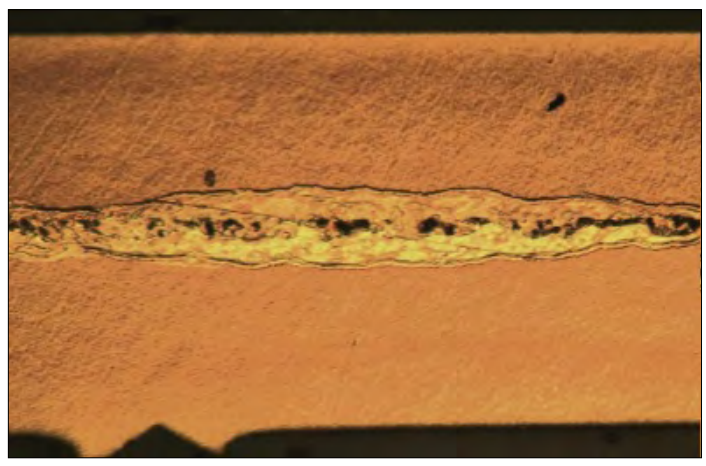

10. ábra. A hegesztés során az összekapcsolódó felületek megolvadtak

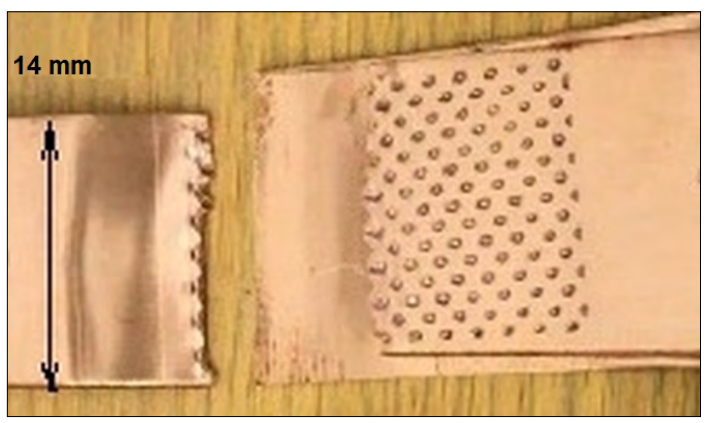

11. ábra. Hegesztett lemez törése 
A hegesztett kötéssel szembeni követelmény a szemrevételezéssel történő ellenőrzés, valamint a kötés szilárdságának ellenőrzése szakítóvizsgálattal, a maximális erő meghatározása, valamint a szakadás helyének elemzése.

A próbatestek hegesztésénél alkalmazott változókat az 1. táblázatban foglaltuk össze. A tartónyomás és a hegesztési nyomásértékek változatlanok voltak a hegesztés során (0,17 MPa).

\section{Következtetések}

A kísérletek eredményeit az 1. táblázat tartalmazza. A hegesztési kísérletek alapján látható, hogy a hegesztési idő változása jelentős hatással volt a varrat kialakulására és az eltérésekre (deformáció, repedés, túlzott hő miatti elszíneződés, varratban történő olvadás).

A repedések minden esetében a hosszabb hegesztési idő, hosszabb idejü ultrahangos hatás eredményeként jöttek létre. A réz fáradási szilárdsága a vibráció hatására csökken, ezért a terhelés hatására repedés, törés jön létre.

A felületek túlhevülése („megégése”) azokban az esetekben volt megfigyelhető, amikor nagy amplitúdót és nagy hegesztési időt együttesen alkalmaztunk.

Azt is megállapítottuk, hogy nagy amplitúdóval, de rövid hegesztési idővel nem jön létre megfelelő kötés.

Az amplitúdó és a hegesztési idő értéke alapján a keletkező hő meghatározható, ennek az összefüggésnek a meghatározásához még további kísérletek szükségesek.

\section{További tervek}

Mivel a réz fáradási szilárdságát a vibráció csökkenti, további kísérletekkel ezt a hatást bizonyítani szeretnénk.

A kötés mikroszerkezeti változását és ennek a szilárdsággal való összefüggését szintén további vizsgálatok eredményeiből kívánjuk meghatározni.

\section{Köszönetnyilvánítás}

A szerző köszönetet kíván mondani Alvincz Gergely és Rakymzhan Meruyert hallgatóknak a kísérletekben nyújtott segítségükért, valamint a magyar államnak és az Európai Uniónak az EFOP-3.6.1-162016-00010. számú projekt keretében nyújtott támogatásért.
1. táblázat. A hegesztési változók, ahol A az amplitúdó ( $\mu \mathrm{m})$, t a hegesztési idő (s)

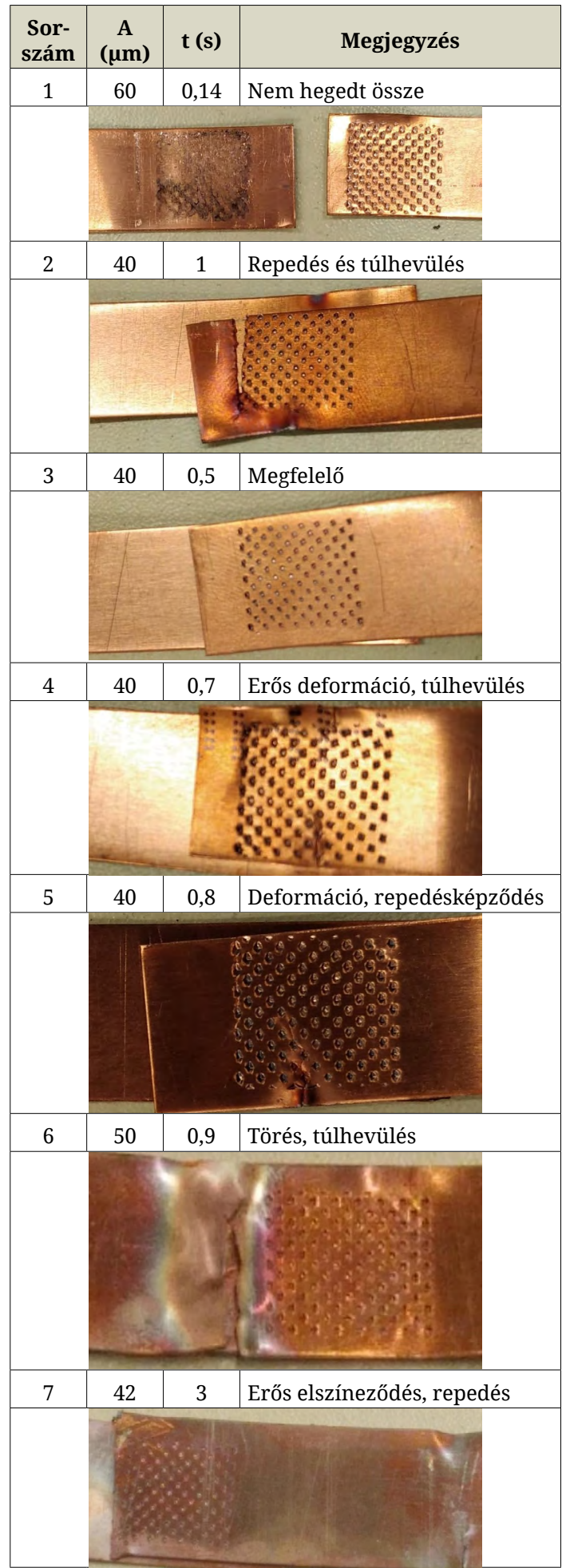




\section{Szakirodalmi hivatkozások}

[1] Bagyinszky Gy., Bitay E.: Ultrahangos hegesztés alkalmazástechnikai jellemzői. In: A XXIII. Fiatal müszakiak tudományos ülésszak előadásai. Proceedings of the $23^{\text {th }}$ international scientific conference of youngth engineers, Kolozsvár/Cluj, Románia, Müszaki Tudományos Közlemények 7. (2018) 31-34. http://eda.eme.ro/handle/10598/30312

[2] Haikkinen S.: Fatigue of Metals, Copper Alloys, 2003.

http://clic-meeting.web.cern.ch/clic-meeting/2003/06_26sh.pdf

[3] University of Ljubljana: ESDEP oktatási segédlet. 2018. (letöltve: 2018. március 22.)

http://fgg-web.fgg.uni-lj.si/ /pmoze/esdep/master/wg12/10200.htm

[4] $\mathrm{Wu} \mathrm{X}$ et al.: Microstructure, welding mechanism, and failure of $\mathrm{Al} / \mathrm{Cu}$ ultrasonic welds. Journal of Manufacturing Processes 20. (2015) https://doi.org/10.1016/j.jmapro.2015.06.002

[5] Astashev V. K., Babitsky V. I.: Ultrasonic Processes and Machines, Dynamics, Control and Applications. Springer-Verlag, Berlin-Heidelberg, 2007. 33-45.
[6] Abramov O. V.: High-Intensity Ultrasonics: Theory and Industrial Applications. $1^{\text {st }}$ Edition, CRC Press Published 1999. Januar 18.

[7] Bagyinszki Gy., Bitay E.: Hegesztéstechnika II. Berendezések és mérések. Müszaki Tudományos Füzetek 10., EME, Kolozsvár/Cluj, 2010. 286. http://eda.eme.ro/handle/10598/15438

[8] Langford G.: Microstructures. Massachusetts Institute of Technology, Cambridge, MA, Non Ferrous Alloys 1966. https://www.georgesbasement.com/Microstructures/NonFerrousAlloys/Lesson-1/Specimen01. htm

[9] Bagyinszki Gy., Bitay E.: Hegesztéstechnika I. Eljárások és gépesítés. Műszaki Tudományos Füzetek 9., EME Kolozsvár/Cluj, 2010. 288. http://eda.eme.ro/handle/10598/15437

[10] Szilágyi M., Kovács T.: Thin aluminium sheets ultrasonic welding. Hegesztéstechnika, Budapest, 2016.

[11] Szilágyi M., Kovács T.: Ultrasonic Welding process in case of aluminium sheets. In: Proceedings of $8^{\text {th }}$ International Engineering Symposium at Bánki, Budapest, 55. (2016). http://bgk.uni-obuda.hu/iesb/2016/publication/55.pdf 